\title{
PRASASTI TALANG TUO PENINGGALAN KERAJAAN SRIWIJAYA SEBAGAI MATERI AJAR SEJARAH INDONESIA DI SEKOLAH MENENGAH ATAS
}

\author{
Kabib Sholeh \\ Pendidikan Sejarah Universitas PGRI Palembang \\ Email: habibsholeh978@gmail.com
}

\begin{abstract}
Abstrak
Tujuan penelitian ini adalah menganalisis sejarah awal munculnya kerajaan Sriwijaya, untuk menganalisis isi prasasti Talang Tuo dalam perkembangan agama Budha, mengetahui prasasti Talang Tuo sebagai materi ajar Sejarah Indonesia di Sekolah Menengah Atas. Metode penelitian yang digunakan pada penelitian ini adalah metode historis dengan pendekatan keilmuan teologis, politikologis, antropologis dan sosialogis. Langkah-langkah metode historis adalah heuristik atau pengumpulan sumber, verifikasi sumber, interpretasi atau penafsiran sumber dan historiografi atau penulisan sejarah. Hasil penelitian menunjukan Prasasti Talang Tuo adalah prasasti peninggalan kerajaan Sriwijaya yang menjelaskan tentang perkembangan agama Budha di Sriwijaya, dijelaskan ketaatan raja Dapunta Hiyang Sri Jayanasa dalam menjalankan ajaran Budha sekaligus sebagai simbul wakil dewa di dunia. Analisis isi prasasti Talang Tuo tentang perkembangan agama Budha di Sriwijaya dapat memperkaya materi ajar Sejarah Indonesia di Sekolah Menengah Atas. Relevansi analisis isi prasasti Talaang Tuo dapat dijadikan materi ajar adalah sesuai dengan silabus Sejarah Indonesia Sekolah Menengah Atas yaitu tepatnya pada Kompetensi Dasar (KD) 3.5 dan 3.6 yaitu perkembangan kerajaan-kerajaan yang bercorak Hindu-Budha di Indonesia pada submateri tentang perkembangan kerajaan Sriwijaya.
\end{abstract}

Kata Kunci: Kerajaan Sriwijaya, prasasti Talang Tuo, materi ajar, Sejarah Indonesia.

\section{Abstract}

The purpose of this study is the beginning of the history of the kingdom of Sriwijaya, to analyze the contents of Talang Tuo inscriptions in the development of Buddhism, looking for Talang Tuo inscriptions as a teaching material of History of Indonesia in High School. The research method used in this study is the historical method and the type of descriptive qualitative research. These steps are the source or source, interpretation or interpretation of the source and historiography.

The result of the research shows the inscription of Talang Tuo is an inscription of Sriwijaya royal heritage that explains about the development of Buddhism in Sriwijaya, described the obedience of King Dapunta Hiyang Sri Jayanasa in practicing Buddhism as well as the symbol of the deputy god in the world. Analysis of the contents of Talang Tuo inscriptions on the development of Buddhism in Sriwijaya can enrich the subject of History of Indonesia in High School. Relevance of content analysis of inscription Talaang Tuo can be used as teaching material is in accordance with syllabus of History of High School of Indonesia which is precisely on Basic Competence (KD) 3.5 and 3.6 that is development of HinduBuddhist kingdom in Indonesia on submateri about development of Sriwijaya kingdom.

Keywords: Sriwijaya Kingdom, Talang Tuo inscriptions, teaching materials, History of Indonesia.

\section{PENDAHALUAN}

Pembelajaran mata pelajaran

Sejarah Indonesia di sekolah menengah atas salah satu materinya mengenai sejarah kerajaan Sriwijaya dan sekaligus perkembangan agam Budha di pusat Sriwijaya di Palembang, dapat dikaji lebih dalam informasi peristiwa tersebut dengan menafsirkan atau menganalisis isi dari prasasti peninggalan kerajaan Sriwijaya yaitu prasasti Talang Tuo yang ditemukan di Palembang dan tentunya analisis tersebut analisis isi yang sudah ditranslitkan oleh para pakar terdahulu. 
Dengan demikian hasil analisis yang terbaru tidak menutup kemungkinan akan bermanfaat dan menambah kayanya inti dari submateri tentang perkembangan masa kerajaan Sriwijaya yang berpusat di Palembang.

Palembang merupakan kota yang dikenal sejak lama sebagai salah satu kota tertua di Indonesia. Sejarah perkembangan kota Palembang dari masa awal berdiri sampai sekarang memang tidak akan ada habisnya apa bila dikaji baik dari segi sejarah, sosialbudaya, ekonomi, politik dan agamanya. Kerajaan Sriwijaya yang terletak di Palembang dalam catatan sejarahnya dapat dijelaskan oleh para ilmuan sejarah sebagai kerajaan besar yang bercorak maritim sebagai maharaja penguasa di laut seluruh Nusantara bahkan kekuasaannya sampai seluruh perairan Asia Tenggara yang dikuasai Sriwijaya pada abad ke-7 sampai abad ke-13 M.

Penjelasan mengenai Sriwijaya yang bercorak Budha mungkin selama ini hanya diperoleh informasi berdasarkan temuan-temuan berupa arca Budha dan keterangan I-Tsing dalam catatan perjalanan suci yang bertolak dari Kanton (Cina) menuju Nalanda (India) pada tahun $671 \mathrm{M}$. dalam perjalanannya tersebut I-Tsing sempat singgah di pusat kerajaan Sriwijaya dan ia mencatat terdapat 1000 lebih biksu yang sedang belajar agama Budha dan bahasa sansekerta. Setelah I-Tsing singgah di Sriwijaya kurang lebih dua tahun, maka ia melanjutkan perjalanannya ke Utara menuju Kedah (Semenanjung Malaya) dan dilanjutkan menuju Nalanda (India) (Muljana, 2006:48).

Dengan bukti-bukti berupa berita dari luar dan temuan arca dari dalam maka sekirannya informasi tentang kerajaan Sriwijaya terutama rajanya yang memang memeluk agama budha belum dapat dijelaskan dengan pasti seperti halnya sejauh mana seorang raja Sriwijaya yang besar memahami dan menjalankan ajaran Budha dengan sungguh-sungguh, bagaimana perlindungan terhadap agama Budha sendiri dan sekaligus bagaimana kealiman atau ketaatan seorang raja sehingga berpengaruh dalam pemikiran dan kebijakannya dalam memimpin sebuah kerajaan. Dalam isi prasasti Talang Tuwo tersebut selain menjelaskan tentang pembangunan taman (Srikstra) tetapi ada indikasi sebuah pemaknaan yang mengisyaratkan sebuah ketaatan seorang raja Sriwijaya dalam menjalankan ajaran agamanya.

Mengenai makna yang terkandung dalam prasasti Talang Tuo tentang perkembangan agama Budha Sriwijaya di Palembang tersebut setidaknya dalam silabus Sejarah Indonesia pada Sekolah Menengah Atas terdapat materi tentang perkembangan kerajaan Sriwijaya yang sekaligus sekiranya sesuai apa yang 
menjadi latar belakang yang diuraiakan di atas dapat menamabah dan memperdalam materi ajar tentang perkembangan kerajaan Sriwijaya. Dengan faktor-faktor dan latar belakang yang sudah diuraikan di atas, penulis tertarik untuk membahas analisis prasasti Talang Tuo sebagai materi ajar Sejarah Indonesia di Sekolah Menengah Atas.

Adapun tujuan pada penelitian ini adalah (1) Untuk menganalisis sejarah perkembangan kerajaan Sriwijaya pada abad ke-7 Masehi; (2) Untuk menganalisis isi prasasti Talang Tuo bagi perkembangan agama Budha di Sriwijaya; (3) Untuk meganalisis prasasti Talang Tuo sebagai materi ajar Sejarah Nasional Indonesia di Sekolah Menengah Atas.

\section{Kerajaan Sriwijaya}

Kata Sriwijaya sendiri dijumpai pertama kali pada tulisan yang terdapat dalam prasasti peninggalan Sriwijaya yaitu prasasti Kota Kapur yang ditemukan di Bangka. Berdasarkan hasil telaah H.Kern pada tahun 1913 tentang isi tulisan pada prasasti tersebut, maka ditemukan kata "Sriwijaya" oleh H. Kern yang beranggapan nama seorang raja. Namun pada tahun 1918, G. Coedes dengan menggunakan sumber-sumber prasasti peninggalan Sriwijaya lainnya dan berita Cina, ia berhasil menjelaskan bahwa kata Sriwijaya yang terdapat pada tulisan prasasti Kota Kapur adalah nama sebuah kerajaan di Sumatera Selatan, dengan pusatnya Palembang.

Kerajaan Sriwijaya dalam berita Cina dikenal dengan sebutan She-li-foshe, menurut G. Coedes bahwa nama Shili-fo-she adalah sebuah kerajaan di pantai Timur Sumatera Selatan, di tepi sebuah sungai dekat Palembang. Selain itu juga keberadaan Sriwijaya di Palembang juga pernah dikemukakan oleh Samuel Beal (1884) hanya disaat itu orang belum mengenal nama Sriwijaya (Poesponegoro, 1990:53).

Hal yang menarik tentang kerajaan Sriwijaya adalah kemunculan dan perkembangannya. Catatan dari Cina yaitu l-tsing tahun 671 Masehi ia menceritakan pelayarannya dari Kanton ke Shi-li-foshi, pusat pemerintahan kerajaan Sriwijaya. Dalam jangka waktu 24 tahun kerajaan itu sudah menjadi sangat kuat dimana sebelum ia kembali ke Cina pada tahun 695 Masehi, Kedah yang berada di pantai Barat Semenanjung Melayu Selatan telah menjadi wilayah vasal Sriwijaya. Pada tahun 775 Masehi, kerajaan Sriwijaya telah menjadi begitu terkenal sehingga penguasanya disebut "Raja yang dipertuan dari Sriwijaya, raja tertinggi diantara semua raja di muka bumi" (Wolters, 2011:1). Dengan demikian kerajaan Sriwijaya begitu terkenal pada masa itu sebagai kerajaan yang berkuasa di laut atau penguasa maritim di Nusantara. 


\section{Prasasti Talang Tuwo}

Kata prasasti berasal dari bahasa sansekerta, arti sebenarnya adalah “Pujian". Tapi kemudian dianggap sebagai "Piagam, maklumat, surat keputusan, undang-undang atau tulisan". Meskipun pengertian awal sebagai pujian, tidak semua prasasti memuat pujian (raja). Sebagian besar prasasti yang dikenal untuk membuat keputusan tentang pembentukan daerah pedesaan atau daerah menjadi maju. Prasasti merupakan sebuah peninggalan sejarah berupa batu yang bertulis tulisan kuno yang beisikan mengenai sebuah berita, informasi, peringatan, undang-undang dan yang lainnya.

Prasasti Talang Tuo adalah prasasti peninggalan kerajaan Sriwijaya yang ditemukan pada tahun 1920 oleh pejabat Inggris yaitu L.C. Westenegh, di daerah Talang Tuo (Talang Kelapo sekarang), prasasti ini dibuat pada masa raja Dapunta Hiyang Sri Jayanasa. Prasasti ini bertanggal 2 bulan Shaitra tahun 606 Saka (684 M), yang terdiri atas 14 baris dengan berbahasa Melayu Kuno (Mahmud, 2007:24). Secara garis besar, prasasti ini menerangkan bahwa pemerintahan baru mengeluarkan undang-undang pertama yaitu berupa pembangunan taman yang disebut Sriksetra. Pada taman tersebut terdapat berbagai macam tanaman yang bermanfaat bagi masyarakat bumi Sriwijaya. Tujuanya ialah untuk kesejahteraan dan kemakmuran seluruh makhluk hidup di bumi Sriwijaya sehingga masyarakat sejahtera dan tentram.

\section{Sumber Materi Ajar Sejarah Indonesia}

Materi ajar adalah seperangkat sarana atau alat pembelajaran yang berisikan materi pokok pembelajaran. Pengertian ini menjelaskan bahwa materi ajar haruslah dirancang dan ditulis dengan kaidah intruksional karena akan digunakan oleh guru untuk membantu dan menunjang proses pembelajaran. Materi pembelajaran pada dasarnya adalah "isi" dari kurikulum, yakni berupa mata pelajaran atau bidang studi dengan topik/subtopik dan rinciannya (Fathurrohman, 2007:23). Melihat penjelasan di atas, dapat kita ketahui bahwa peran seorang guru dalam merancang ataupun menyusun materi ajar sangatlah menentukan keberhasilan proses belajar dan pembelajaran.

Sedangkan Sejarah Indonesia merupakan mata pelajaran yang diajarkan di sekolah, pengertian sejarah sendiri adalah ilmu yang mempelajari peristiwa-peristiwa masa lampau yang benar-benar terjadi, sistematis, kronologis, dan memiliki manfaat bagi masyarakat sebagai kelanjutan dalam kehidupan kedepan yang lebih baik lagi. Sejarah yang dihubungkan dengan Indonesia berarti materi yang membahas mengenai peristiwa-peristiwa masa lampau yang pernah terjadi di Indoensia 
sebagai bagian perjalanan kehidupan bangsa baik bersiafat politik, ekonomi dan bidang yang lainnya. Materi Sejarah Indonesia adalah materi yang mengajarkan mulai dari masa prasejarah, masa Hindu-Budha, masa Islam, masa kolonial Belanda, pergerakan nasional di Indonesia, masa kemerdekaan Indonesia sampai pasca kemerdekaan Indonesia.

Sejarah Indonesia adalah materi yang selalu berkembang berdasarkan temuan-temuan atau hasil penelitian terbaru sehingga materi sejarah Indonesia membutuhkan pengembangan materi terbaru yang belum pernah diajarkan sebelumnya.

\section{METODOLOGI PENELITIAN}

Penelitian ini menggunakan metode sejarah (historis), dengan dibantu pendekatan keilmuan dari berbagai bidang (multi aproach) seperti keilmuan teologis, politikologis, antropologis dan sosialogis.

Adapun langkah-langkah metode sejarah pada penelitian ini adalah pertama, Pengumpulan Sumber (Heuristik). Pada penelitian ini peneliti mengumpulkan sumber-sumber sejarah berupa buku primer hasil penelitian, sumber kepustakaan (lebrary reseach), dokumen, buku dan jurnal hasil laporan penelitian arkeologi dan laporan-laporan umum yang relevan dengan judul penelitian. Kedua, Verifikasi (Kritik
Sumber). Pada kritik ekstern peneliti melakukan pengujian atas asli atau tidaknya sumber dengan menyeleksi sederhana segi fisik dari sumber yang ditemukan. Pada kritik intern ini peneliti melakukan kritik pada isi sumber tersebut mengenai keaslian isi sumber seperti halnya mengidentifikasi informan atau pengarang buku/dokumen, apa penulisan atau pelaporan sumber itu benar, rasional dan logis dengan melihat fakta-fakta yang ada maupun teori yang lain.

Ketiga, Interpretasi. Pada langkah ini setelah dilakukan pembacaan-pembacaan sumber sejarah secara kritis, maka dilakukan penguraian-penguraian atas sintesissintesis yang dikemukakan oleh beberapa ahli dalam teori-teorinya maupun faktafaktanya, maka setelah itu diuraikan kemudian dihubungkan suatu fakta dengan fakta lain sehingga dapat dianalisis dengan benar dan baik. Terakhir, Penulisan Sejarah (Historiografi). Sebagai fase terakhir dalam metode sejarah adalah historiografi yang artinya cara penulisan, pemaparan, atau pelaporan hasil penelitian sejarah yang telah dilakukan peneliti (Daliman, 2015: 98).

\section{HASIL DAN PEMBAHASAN}

\section{Masa Awal Kerajaan Sriwijaya}

Kerajaan Sriwijaya merupakan kerajaan yang sudah dikenal luas seluruh Nusantara maupun di luar Nusantara 
sebagai kerajaan maritim yang berkuasa di laut. Sebelum G. Coedes menulis karangan yang fenomenal berjudul "Le Royaume de Criwijaya" yang artinya Kedatuan Sriwijaya, pada tahun 1718, E. Renaoud telah menerjemahkan naskah Arab yang berjdul “Akhbaru s-Shin wa ‘Hind" (kabar-kabar Cina dan India) yang ditulis oleh seorang musafir Arab yang bernama Sulaiman pada tahun 851 Masehi, naskah tersebut menceritakan adanya sebuah kerajaan besar di daerah Zabaj (Jawa) (Suryanegara, 2009:14).

Istilah atau kata "Jawa" yang dimaksudkan oleh orang Arab pada masa itu adalah seluruh wilayah kepulauan Indonesia saat ini. Selanjutnya pada tahun 1845, Reinaud menerjemahkan catatan Abu Zaid Hasan yang mengunjungi Asia Tenggara pada tahun 916 Masehi, dalam catatan tersebut menjelaskan bahwa maharaja Zabaj bertahta di negeri Syarbazah yang ditransliterasikan oleh Reinaud menjadi Sribuza (Suryanegara, 2009:14). Istilah nama Syarbazah atau Sribuza yang dimaksud dalam berita dari Arab tersebut adalah Kerajaan Sriwijaya yang berkuasa, letaknya di Nusantara sekaligus penguasa maritim terbesar yang ada di Nusantara pada masa itu.

Catatan atau kronik Cina yang berasal dari abad ke-7 dan ke-8 Masehi banyak menyebutkan keberadaan sebuah negara atau kerajaan di laut Selatan yang bernama Shi-li-fo-shi (Siregar, 2010:12).
Setelah melalui penelaahan yang mendalam oleh para pakar sejarah maka disepakati bahwa Shi-li-fo-shi merupakan transliterasi dari Sriwijaya (Kerajaan Sriwijaya). Sumber-sumber berita dari negeri Cina menyebutkan keberadaan Sriwijaya berdasarkan kronik Dinasti Tang (618-902 M), kronik perjalanan pendeta Budha l-tsing (671 M), kronik Dinasti Sung (960-1279 M), kronik Ling-wai tai-ta oleh Chou Ku Fei (1178 M), kronik Chu-fan-chi oleh Chau Ju-Kua (1225 M), kronik Dinasti Ming (1368-1643 M), dan kronik Ying-yai Sheng-lan oleh Ma Huan (1416 M) (Suryanegara, 2009:15). Bukti-bukti informasi dari luar tersebut menyatakan memang di Nusantara pada awal abad ke7 Masehi sudah berdiri sebuah kerajaan besar di Nusantara yang pusatnya sendiri menurut catatan perjalanan l-tsing, Sriwijaya berpusat di tepi sungai (Musi sekarang) wilayah Tenggara dari Melayu yaitu Palembang Sumatera Selatan.

Informasi tentang bukti munculnya Kerajaan Sriwijaya di Palembang dijelaskan dalam catatan perjalanan seorang pendeta Cina pada tahun 671 Masehi yang bernama l-tsing. la melakukan perjalanan bertolak dari Kanton (Cina) sekitar 20 hari maka l-tsing sampailah di pusat kerajaan Sriwijaya. Itsing singgah di pusat Sriwijaya selama 6 bulan untuk mempelajari bahasa Sansekerta dan ajaran agama Budha (Mulyana, 2006:43). Dalam 
perjalanannya, ia mencatat bahwa pusat kerajaan Sriwijaya di kelilingi oleh benteng-benteng dan terdapat seribu lebih pendeta yang sedang belajar agama Budha (Codes, 2010:124). Corak Kerajaan Sriwijaya yang memeluk agama Budha memang tidak terbantahkan apabila melihat bukti-bukti yang ada atau catatan seperti yang ditulis oleh I-tsing tentang para pendeta yang kurang lebih seribuaan pendeta berada di pusat kerajaan Sriwijaya.

Pendapat G. Coedes menjelaskan ketika I-tsing pulang dari Nalanda (India), setelah ia tinggal di Nalanda (India) selama sepuluh tahun, maka ketika Itsing pulang kembali ke Cina, ia singgah terlebih dahulu ke pusat kerajaan Sriwijaya (Fo-shih). I-tsing tinggal di Sriwijaya kurang lebih empat tahun untuk menyalin serta menerjemahkan teks-teks Budhis dari bahasa Sansekerta ke bahasa Cina. Naskah-naskah yang ditulis l-tsing dari Nalanda tersebut mencapai 4.000 naskah (Mulyana, 2006:47). Dengan demikian dapat dijelaskan bahwa Kerajaan Sriwijaya merupakan kerajaan yang memang benar-benar konsen penganut yang taat agama Budha dan sekaligus pelindung agama Budha.

Bukti lain mengenai permualaan munculnya kerajaan Sriwijaya tidak hanya dibuktikan dalam hal informasi yang ditulis dari pendeta Cina, tetapi bukti tersebut berasal dari dalam negeri seperti ditemukannya prasasti-prasasti yang tersebar di wilayah Palembang maupun di luar Palembang. Sebagian besar prasasti-prasasti yang ditemukan tersebut berbahasa Melayu kuno dan berhuruf Pallawa. (Poesponegoro, 1990:53-54). Prasasti-prasasti tersebut diantaranya adalah Prasasti Kedukan Bukit (Palembang), Prasasti Talang Tuo (Palembang), Prasasti Bom Baru, (Palembang), Perasasti Telaga Batu (Palembang), Prasasti Kota Kapur (Pulau Bangka), Prasasti Karang Berahi (Jambi), Prasasti Palas Pasemah (Lampung), dan masih banyak yang lainnya. Selain bukti prasasti-prasasti tersebut ditemukan juga oleh para arkeolog berupa fragmen, manik-manik, arca, dan keramik masa dinasti Cina yang sebagian besar semua temuan tersebut ditemukan di wilayah Palembang dan sekitarnya.

Sesuai dengan bukti dan tanggal ataupun tahun paling tua pada semua prasasti tersebut adalah Prasasti Kedukan Bukit yaitu pada tahun 682 atau abad ke-7 Masehi, sehingga memberikan bukti bahwa Palembang pada masa itu sudah berdiri sebuah kerajaan yang bernama Kerajaan Sriwijaya. Prasasti ini diukir di atas sebuah batu sungai Tatang, yang ditemukan di kaki Bukit Seguntang wilayah Palembang bagian Barat. (Djavid, 1961:5). Maksud dari prasasti tersebut menjelaskan mengenai awal mula berdirinya Kerajaan Sriwijaya. Dapunta Hiyang (raja Sriwijaya) dalam 
mendirikan Kerajaan di Palembang, awalnya ia berangkat dari sebuah pusat kerajaan (sebelum Sriwijaya) dengan membawa tentaranya sekitar dua puluh ribuan untuk melakukan perjalanan suci (siddhayatra). Perjalanan suci atau siddhayatra, yang dimaksud para peneliti menyatakan sebuah perjalanan dalam melakukan ekspansi, dan selanjutnya mereka menemukan tempat yang dianggap tepat dan strategis, maka Dapunta Hiyang memerintahkan tentaranya untuk mendirikan sebuah kerajaan di sekitar tepi sungai besar (Musi sekarang) yaitu di Palembang.

Mengenai dimana letak pusat awal Sriwijaya sebelum pindah ke Palembang sampai sekarang belum ada yang bisa memastikan, tetapi dalam berita Cina pernah menyebutkan bahwasannya pendahulu sebelum Kerajaan Sriwijaya berdiri bernama KanTo- $L i$, yang letaknya juga dalam berita Cina disebutkan di sekitar wilayah Palembang sekarang (Read, 2008:78). Ada sebagian peneliti yang menyatakan pusat awal Sriwijaya sebelum pindah di Palembang adalah di Minanga, seperti yang tertulis dalam Prasasti Kedukan Bukit. Tetapi yang dimaksud Minanga tersebut di mana lokasinya sampai sekarang juga masih menjadi perdebatan bagi kalangan sejarawan.

Kemudian setelah tahun $682 \mathrm{M}$ Sriwijaya sudah berdiri dengan suka cita dan kebahagian, ditambahkan pula informasi ditemukannya Prasasti Talang Tuo di wilayah Palembang bagian Barat pada tanggal 23 Maret 684 Masehi, yang isinya yaitu Dapunta Hiyang Srijayanasa memerintahkan kepada bawahannya untuk mendirikan sebuah taman srikestra namanya. Taman yang didirikan tersebut berupa kebun, buah-buahan beraneka ragam untuk kesejahteraan semua makhluk atau masyarakat.

Pada prasasti tersebut raja Sriwijaya seakan-akan menyampaikan pesan dengan membuat sebuah prasasti yang isinya mengungkapkan harapanharapan semoga pendirian taman ini (sriketsra) dapat menjadikan masyarakat Sriwijaya makmur dan sejahtera serta mengungkapkan harapan-harapan rasa syukur dengan doa-doa semoga semua mahluk mendapatkan ridho dan kemulyaan. Keterangan tersebut seakanakan ingin menegaskan bahwa raja Sriwijaya yang mendirikan sebuah taman selayaknya taman kota pada masa sekarang, yang artinya pendirian taman tersebut pasti tidak jauh dengan pusat kota. Sesuai lokasi ditemukannya prasasti Talang Tuo di wilayah sekitar wilayah Talang Kelapa, Palembang bagian Barat yang tidak jauh dengan tepi Sungai Musi. Dapat ditegaskan juga kalau pusat kerajaan Sriwijaya ada di Palembang dan tidak mungkin di tempatkan di luar Palembang, karena secara tatanan perkotaan juga tidak akan sesuai seperti 
penjelasan yang diperoleh dari prasastiprasasti di Palembang.

\section{Perluasan Kekusaan}

Besar kemungkinan negeri yang ditaklukkan terlebih dahulu oleh Sriwijaya adalah pulau Bangka. Bukti penaklukkan di Pulau Bangka adanya temuan prasasti Kota Kapur yang berangka tahun $686 \mathrm{M}$. Prasasti ini ditemukan pada tahun 1892, di lahan yang dikelilingi benteng tanah di tepi Sungai Mendo, desa Kota Kapur (Suryanegara, 2009:20). Isi prasasti tersebut berupa ancaman atau kutukan yang biasa disebut prasasti persumpahan. Prasasti tersebut menjelaskan bagi siapa saja yang tidak tunduk kepada raja Sriwijaya maka akan di bumi hanguskan dan dijelaskan pula dalam tulisan prasasti tersebut terdapat kalimat penaklukan "Bumi Jawa" yang artinya penaklukan tersebut atas dasar keinginan untuk membuka jalur dalam memudahkan masuk menyebrangi wilayah tanah Jawa dengan maksud untuk menguasai Selat Sunda terlebih dahulu.

Setelah Pulau Bangka dan sekitarnya dapat dikuasi oleh tentara Sriwijaya, maka selanjutnya Sriwijaya bergerak melakukan ekspansinya ke arah Selatan yaitu menuju wilayah Lampung. Penaklukkan wilayah lampung dibuktikan dengan ditemukannya Prasasti Palas Pasemah pada tahun 1958, yang ditemukan di Wai Pisang Lampung
Selatan (Rapanie, 2012:43). Isi prasasti tersebut pada intinya terdapat kesamaan dengan prasasti yang ditemukan di Pulau Bangka yaitu berupa kutukan atau prasasti persumpahan bagi siapa saja yang melawan atau menentang raja Sriwijaya maka akan mendapatkan kutukan dari raja Sriwijaya. Tentara Sriwijaya dengan kekuatan yang besar dapat berhasil dengan mudah menaklukkan wilayah Lampung yang diduga pada masa itu memang ada penguasa kecil di Lampung, tetapi pada akhirnya menjadi daerah vasal Sriwijaya yang harus tunduk dan mengakui kekuasaan Sriwijaya di Palembang.

Selain Prasasti Palas Pasemah, ditemukan juga Prasasti Bungkuk di wilayah Lampung Tengah, prasasti ini tidak tertera tanggal tetapi diduga masih sezaman dengan prasasti-prasasti yang lain yaitu sekitar abad ke-7 M. Prasasti Bungkuk ini sebagaimana halnya dengan prasasti-prasasti persumpahan lainnya berisi tentang kutukan atau ancaman kepada siapa saja yang berani melakukan pemberontakan atau tidak setia kepada raja Sriwijaya. Lokasi penemuan prasasti yang relatif jauh dari pusat Kerajaan Sriwijaya membuktikan bahwa di daerah ini memerlukan semacam upaya pengamanan atau pencegahan agar tidak terjadi pemberontakan yang ingin melepaskan diri dari kekuasaan Sriwijaya. 
Pada tanggal 28 Februari 686 Masehi tentara Sriwijaya berangkat menyerbu Pulau Jawa, seperti yang dijelaskan pada prasasti yang ditemukan di Pulau Bangka yaitu Prasasti Kota Kapur. Pada masa itu Kerajaan Taruma di Jawa Barat masih berdiri, sebab pada masa yang sama Kerajaan Tarumanegara masih mengirimkan utusan ke negeri Cina. Sesudah itu nama Tarumanegara menghilang dari catatan kronik Cina. Kiranya Kerajaan Tarumanegara juga menjadi korban ekspansi tentara Sriwijaya. Kondisi yang demikian diperkuat pernyataan Slamet Mulyana yang mennyatakan bahwa tulisan dalam Prasasti Kota Kapur yang ditemukan di Pulau Bangka yaitu "Bhumi Jawa" ditafsirkan sebagai Tanah Jawa (Mulyana, 2006:156). Jika demikan, ekspansi yang dilakukan tentara Sriwijaya pada masa itu ditujukan terhadap Jawa, pertama-tama terhadap Kerajaan Tarumanegara di Jawa Barat, yang selanjutnya melakukan perluasan di seluruh bagian tanah Jawa.

Kemudian tentara Sriwijaya bergerak ke Utara untuk menaklukkan negeri Melayu (Jambi). Penaklukkan wilayah Jambi merupakan penaklukkan sangat penting bagi Sriwijaya sebab Jambi merupakan wilayah pelabuhan yang sangat ideal tempatnya. Bukti penaklukkan tersebut berupa ditemukannya prasasti Persumpahan yaitu Prasasti Karang Berahi. Prasasti ini merupakan satu-satunya prasasti yang ditemukan di wilayah Jambi, tepatnya di tepi Sungai Merangin, dalam keterangannya prasasti ini tertanggal pada abd ke-7 Masehi (Tim Museum Balaputra Dewa, 2010:55. Isi yang terkandung dalam prasasti ini hampir sama dengan prasasti-prasasti persumpahan yang ditemukan di Bangka dan di Lampung Selatan.

Wilayah Jambi merupakan wilayah yang sangat penting untuk dikuasai oleh Sriwijaya mengingat Jambi harus dikuasi sebagai batu loncatan untuk menguasai jalur pelayaran dan perdagangan di wilayah Selat Malaka. Bukti penaklukan Jambi (Melayu) menjadi wilayah Sriwijaya adalah pernyataan l-tsing ketika pulang dari India (Nalanda) tahun 685 Masehi yang menyatakan bahwa Jambi atau Melayu sudah menjadi bagian dari Sriwijaya (Mulyana, 2006:46). Penaklukkan wilayah Jambi tersebut merupakan penaklukkan yang sangat penting bagi Sriwijaya untuk mencapai tujuan sebagai kerajaan yang berkuasa di lautan.

Selanjutnya tentara Sriwijaya menyeberangi lautan ke arah Utara sambil menaklukkan wilayah-wilayah pelabuhan yang ada di pesisir pantai Timur Sumatera untuk menuju Selat Malaka dan menduduki daerah Semenanjung Malaka. Sasaran utama adalah negeri Kedah dan sekaligus mengendalikan pelayaran perdagangan 
di sekiar peraiaran Selat malaka di bawah pengawasan tentara maritim Sriwijaya (Suryanegara, 2009:25). Selat Malaka merupakan wilayah yang sangat strategis bagi pelayaran dan sangat ramai pada masa pelayaran perdagangan masa itu. Selain itu juga, Malaka merupakan tempat persinggahan pertama kapalkapal yang datang dari Samudera Hindia ketika memasuki wilayah Nusantara.

Bukti adanya perluasan kekuasaan Sriwijaya sampai menjadi kekuasaan maritim terbesar di jalur pelayaran perdagangan hingga sampai wilayah Thailand Selatan adalah ditemukannya Prasasti Ligor di Thailand Selatan (Tim Arkeologi, 2006:63). Prasasti ini terdiri dari dua sisi yaitu sisi A dan sisi B. Pada sisi A seluruh teksnya ditulis dalam bahasa Sansekerta dan berisi ujian terhadap seorang raja Sriwijaya yang tak bernama, juga disebutkan bangunan agama Budha yang didirikan pada tahun 775 Masehi.

Kekuatan tentara Sriwijaya yang besar menjadikan kuatnya hegemoni di laut seluruh Nusantara dan di luar Nusantara. Perluasan yang lakukan tersebut bukan hanya semata-mata untuk mencari kekuasaan dan wilayah yang luas, tetapi Sriwijaya memegang prinsip sesuai dengan ajaran Budha yaitu untuk selalu berbuat baik kepada sesama manusia yang melakukan kebaikan dan tidak melawan dengan raja Sriwijaya. Bukti dengan mendirikannya tempat beribadatan agama Budha seperti keterangan pada Prasasti Ligor di atas memberikan gambaran betapa Sriwijaya memaknai arti penaklukkan di daerah vasalnya bukan untuk dijadikan wilayah yang harus ditindas dengan kekerasan. Seluruh wilayah vasal Sriwijaya pada umumnya bukan takut untuk dijajah dan ditindas daerahnya tetapi karena Sriwijaya dapat masuk ke wilayah tersebut oleh sebab Sriwijaya dipandang sebagai kerajaan yang disegani dan memiliki karismatik untuk penguasanya di laut. Dalam catatan-catatan yang ada baik berita dalam negeri maupun luar negeri, Sriwijaya tidak pernah melakukan peperangan kepada wilayah vasalnya kecuali wilayah vasal tersebut membangkang terhadap raja Sriwijaya. Semuanya dimungkinkan karena Sriwijaya sebagai penguasa maritim memiliki karismatik dan disegani oleh para daearah vasalnya. Justru ajaranajaran Budhisnya yang selalu diajarkan kepada penguasa-penguasa vasalnya. Seperti contoh pendirian tempat peribadatan tersebut mengajak para bawahannya untuk selalu mengingatkan ajaran-ajaran Budhisme dengan penuh keiklasan dan berbuat baik terhadap sesama manusia.

Usaha melebarkan kekuasaan Sriwijaya ke arah India juga dibuktikan dengan catatan atau perjalanan pendeta dari Cina. Ketika I-tsing pulang dari India tahun 685 ia mengatakan bahwa Kedah 
sudah menjadi kekuasaan Sriwijaya (Mulyana, 2006:47). Selain itu juga peninggalan berupa prasasti telah ditemukan, yaitu Prasasti Nalanda. Prasasti ini ditemuakan di Nalanda (India), berangka tahun sekitar $860 \mathrm{M}$. Kekuasaan Sriwijaya perluasannya sampai ke wilayah India dan seluruh laut Samudera Hindia dapat dikuasai oleh Sriwijaya. Dengan demikian wilayah jalur pelayaran yang dimulai dari India, Selat Malaka sampai ke Selat Bangka dan Selat Sunda pada masa abad ke-8 sampai abad ke-9 Masehi dapat dikuasai oleh kekuatan maritim Sriwijaya.

Prasasti Talang Tuo dan Agama Budha di Sriwijaya

Prasasti Talang Tuo di temukan di Palembang oleh L.C. Westenenk pada tanggal 17 November 1920 yaitu di sebelah barat Palembang atau wilayah Talang Tuo tidak jauh dari Bukit Siguntang. Prasasti ini ditemukan dipermukaan tanah dengan kondisi tertelungkup ke tanah dengan kondisi fisiknya baik (Coedes, 2014:55). Prasasti Talang Tuo ini terdapat 14 baris dengan tulisan aksara Palawa dan berbahasa Melayu Kuno dan sekaligus tertulis tahun 606 Saka atau 684 Masehi. Adapun isi dari keempat belas parasasti Talang Tuo dan terjemaahannya menurut Coedes diantaranya adalah (Coedes, 2014:55).

1. // svasti. Sri sakavarsatita 606 dim dvitiya sukalapaksa vulan caitra. Sana tatkalana parlak sriksetra ini. Niparvuat.
2. Parvanda punta hiyam sri jayanasa. Ini pranidhananda punta hiyam. Savanakna yam nitanam di sini. Niyur pinam hanau.ru.

3. Mviya dnan samisrana yam kayu nimakan vuahna. Tathapi haur vuluh pattum ityevamadi. Punarapi yam parlak vukan.

4. Dnan tavad talaga savanakna yam vuatku sucarita paravis prayojanaka punyana sarvvastva sacaracar. Varopayana tmu.

5. Sukha. Di asannakala di antara margga lai. Tmu muah ya ahara dnan air niminumna. Savanakna vuatna huma parlak mancak mu

6. Ah ya mamhidupi pasu prakara. Marhulun tuvi vrdddhi muah ya janan ya niknai savanakna yam upasargga. Pidanu svapnavigna. Varam vua.

7. Tana kathamapi. Anukula yam graha naksatra paravis diya. Nirvyadhi ajara kavuatanana. Tathapi savanakna yam nhtyana.

8. Satyarijava drdhabhakti muah ya dya. Yam mitrana tuvi janan ya kapatayam vinina mulam anukula bharyya muah ya. Varam stha

9. Nana lagi curiuca vadhana paradara di sana. Punarapi tmu ya kalyanamitra. Marvvanun vodhicitta dnan maitri.

10. Dhari di dam hyam ratnatraya janan marsarak dnan dam hyam ratnaraya. Tathapi nityakala tyaga marsila ksanti marvvanun viryya rajin

11. Tahu di samisrana silpakala paravis. Samahitacina. Tmu ya prajna. Snrti medhavi. Punarapi dhairyyamani mahasattva

12. Vajrasarira. Anupamasakti. Jaya. Tathapi jatismara. Avikalendriya. Mancak rupa. Subhaga hasin halap. Ade

13. Yavakya. Vramaswara. Jadi laki. Svayambhu. Punarapi tmu ya cintamanindhana. Tmu janmavasita karmavasita. Klesavasita.

14. Avasana tmu ya anuttarabhisamyaksamvodhi.

Terjemahan :

1. Selamat sejahtera! Pada hari kedua paroterang, Bulan Caitra, Tahun 606 
Saka, saat itulah taman (yang bernama) Sri Ksetra ini dibuat.

2. Punta Hyam Sri Jayanasa wujud pranidhana Punta Hiyam, (dan) hendaknya semua tanaman yang telah ditanam di taman Sri Ksetra ini seperti kelapa, pinang,

3. Aren, dan sagu serta jenis-jenis pohon bambu, seperti bambu haur, bambu (wuluh), dan bambu betung dan sejenisnya. Termasuk pula taman-taman, bendunganbendungan,

4. Telaga-telaga. Semua amal saya berikan hendaknya dipelihara, demi kesejahteraan dan kepentingan seluruh makhluk hidup seperti manusia, binatang (bergerak) dan tanaman (tidak bergerak). Sebagai tempat yang memberi rasa nyaman.

5. Kebahagian. Sebagai tempat beristirahat dan melepaskan lelah bagi mereka yang sedang dalam perjalanan, penawar lapar dan dahaga. Semoga pula kebun-kebun yang ada di taman ini hasilnya berlimpah, sehingga

6. Ternak-ternak terurus karenanya. Demikian pula para juru peliharanya. Semoga mereka senantiasa aman, tenang, nyaman tidur dan berbahagia apapun yang mereka perbuat.

7. Semoga semua yang ada di taman ini dilindungi oleh planet dan rasi serta selalu dalam keberuntungan, awet muda, panjang usianya selama menjalankan tugas mereka. Semoga para hamba

8. Yang setia dan berbakti memelihara taman ini selalu dicintai, keluarganya di karuniai kebahagian. Dan para pengunjung taman ini selalu yang jujur, dari manapun mereka datang dan singgah

9. Tidak ada pencuri, perampas, pembunuh, atau penzinah (pelacur). Selalu itu semoga mereka yang datang merupakan kawan dan penasehat yang baik, dan dalam jiwanya terlahir pikiran Bodhi serta persahabatan (--)

10. Selalu sesuai dan tak terpisah dari ajaran suci tiga ratna. Dan semoga mereka senantiasa (mereka bersikap) murah hati, taat pada peraturan, dan sabar. Semoga dalam diri mereka timbul tenaga, kerajinan.,

11. Pengetahuan, dan seluruh citarasa keindahan. Semoga semangat mereka terpusatkan, mereka memiliki pengetahuan, ingatan kecerdasan. Lagi pula semoga mereka teguh pendapatnya, bertubuh intan seperti mahasattwa,

12. Berkekuatan tiada tara, berjaya dan juga ingat akan kehidupankehidupan mereka sebelumnya, berindera lengkap, berbentuk penuh, berbahagia, bersenyum, tanang,

13. Bersuara merdu seperti suara brahma. Semoga mereka terlahir sebagai pria yang menjadi wadah batu ajaib, mempunyai kekuasaan atas kelahiran-kelahiran, kekuasaan atas karma, dan kekuasaan atas

14. Noda-noda, semoga akhirnya mereka mendapat penerangan yang sempurna dan agung.

Pernyataan P.J. Zoetmulder yang dikutip Kartakusuma, menekankan pentingnya peranan agama dalam kebudayaan dan tidak ada satupun kebudayaan di dunia yang lepas dari pengaruh agama. Oleh sebab itu peninggalan-peninggalan kehidupan manusia yang ditinggalkan sebagian terbesar dari hasil kebudayaan yang disaksikan kini umunya dikususkan bagi tujuan keagamaan. Hal ini menunjukan bahwa hasil kebudayaan yang mencermikan agama lebih bertahan dari hasil kebudayaan yang mencerminkan kehidupan sehari-hari. Kondisi dan kenyataan ini berlaku pula bagi sejarah perkembangan kebudayaan masa Sriwijaya termasuk perkembangan 
agama Budha dan corak kerajaan di Sriwijaya.

Peninggalan kerajaan Sriwijaya memang tidak ada habisnya, semakin hari temuan-temuan berupa manikmanik, barang keramik, prasasti, arca dan masih banyak yang lainnya dapat ditemukan disekitar wilayah Palembang sendiri. Berdasarkan tinggalan prasasti Talang Tuo yang tertera 14 baris dan mengandung makna yang mulya bagi raja Sriwijaya yang telah memberikan gambaran kepemimpinan raja yang bijaksana, adil, tegas dan sekaligus pemimpin yang melindungi agama serta taat dalam menjalankan ajaran agama Budha.

Dalam kultur dan pemahaman penganut agama Hindu-Budha bahwa raja dianggap sebagai wakil dewa di dunia kepercayaan itu disebut kultus dewaraja. Begitu halnya yang terdapat isi pada prasasti Talang Tuo merupakan pernyataan kultus individu dari Dapunta Hiyang Sri Jayanasa. Ajaran Budha kemungkinan manusia mencapai tingkat kedewaan pada saat masih hidup adalah aliran Tantra atau Budha Mahayana. Ajaran Tantrayana di Nusantara terdapat dalam Budha Mahayana merupakan hasil sintese mantrayana (mengutamakan semadi/yoga) dan paramitayana (ilmu pengetahuan tertinggi).

Makna yang terkandung pada isi prasasti Talang Tuo merupakan sebuah pesan dan gamabaran kondisi politik, sosial-budaya, ekonomi dan agama di kerajaan Sriwijaya yang apabila dipahami dengan seksama menunjukan dua hal kondisi yang sedang berkembang maupun kondisi kepemimpinan seorang raja yang sangat taat pada ajaran agama budha. Dapat dikelompokan isi yaang terkandung pada 14 baris pada prasasti Talang Tuo yaitu, pertama tentang ajaran Budha Mahayana (Tantarayana) dan pendirian Taman Sriksetra.

Pembuatan prasasti Talang Tuo oleh raja Sriwijaya telah menggambarkan sebuah kepemimpinan yang sangat religius dalam agama Budha dan sekaligus pemimpin yang adil dan bijaksana kepada rakyatnya. Prasati Talang Tuo adalah usaha Dapunta Hiyank Sri Jayanasa yang bertujuan untuk mensejahterakan pemerintahan dan rakyatnya tertib, teratur sesui dengan dharma sekaligus menyelamatkan rakyatnya dari samsara atau penderitaan dunia. Usaha itu dilakukan pada saat Dapunta Hiyank Sri Jayanasa telah mampu atau dianggap telah mencapai tingkat kedeawaan (sebagai dewa di dunia) dalam masa pemerintahannya. Proses pendewaan ini secara normatif diperoleh melalui Tantra, sebagai dewaraja ia dapat menjangkau pengertian yang luas dalam usaha menyelamatkan segala makhluk atas penderitaannya, dan seluruh wujud usaha itu antara lain adalah pembuatan Taman Sriksetra. 
Taman Sriksetra dibuat pada tahun 606 Saka (684 M), dapat dipahami karena saat itu Dapunta Hiyank Sri Jayanasa baru beberapa waktu mejalani pemerintahannya, sehingga ia perlu mengadakan kultus individu sebagai dewaraja sebagaimana syarat yang harus dipunyai seseorang raja. Uraian Talang Tuwo memang mencerminkan seseoarang yang telah paham dan menghayati ajaran Budha. Pada masa itu Dapunta Hiyank Sri Jayanasa telah menjadi seseorang dewa, sedangkan masa sebelumnya ia belum sampai taraf sedemikian tinggi seperti pernyataan Satyawati Suleiman tahun 1985. Dengan demikian prasasti Talang Tuwo adalah bukti tertulis yang sengaja dibuat sehubungan kepentingan legitimasi dan wujud kultus dewaraja melalui ajaran Budha dari Dapunta Hiyank Sri Jayanasa.

\section{Prasasti Talang Tuwo sebagai Materi} Ajar Sejarah Indonesia di Sekolah Menengah Atas

Isi prasasti Talang Tuo yang sudah diuraikan di atas telah memberikan gambaran yang jelas tentang perkembangan agama Budha di bumi Sriwijaya Palembang. Pembahasan materi pada mata pelajaran Sejarah Indonesia di tingkat Sekolah Menengah Atas atau sederajatnya yaitu pada kelas $X$ semester ganjil yang tertera pada silabus pada Kompetensi Dasar (KD) 3.5 tetang "Menganalisis berbagai teori tentang proses masuk dan berkembangnya agama dan kebudayaan Hindu-Buddha di Indonesia" dan Kompetensi Dasar (KD) 3.6 tentang "Menganalisis karakteristik kehidupan masyarakat, pemerintahan dan kebudayaan pada masa kerajaankerajaan Hindu-Buddha di Indonesia dan menunjukan contoh bukti-bukti yang masih berlaku pada kehidupan masyarakat Indonesia masa kini". Pada Kompetensi Dasar tersebut terdapat pada pokok submateri tentang sejarah perkembangan kerajaan-kerajaan yang bercorak Hindu-Budha di Indonesia yaitu tepatnya pada materi sejarah perkembangan kerajaan Sriwijaya di Palembang.

Pembahasan materi dalam perkembangan agama Budha masa kerajaan Sriwijaya yang keterangan dan bukti-buktinya bersumber pada prasasti Talang Tuo ternyata belum diajarkan secara mendalam dan komprehensif terutama mengenai perkembangan agama Budha di Sriwijaya, dikarenakan kurang mendalamnya pembahasanpembahasan yang diajarkan maupun yang tertera dalam buku-buku pegangan atau buku paket Sejarah, maupun materi ajar yang disampaikan kepada siswa terutama pada perkembangan agama Budha pada masa Sriwijaya. Seperti analisis isi dari prasasti Talang Tuo yang sudah dijelaskan pada uraian 
sebelumnya tentang perkembangan agama Budha di Sriwijaya telah memberikan sumbangsi dan memperkaya materi kelokalan maupun isi meteri yang sesuai pada Kompetensi Dasar 3.5 dan 3.6 tentang perkembangan kerajaan-kerajaan yang bercorak HinduBudha di Indonesia khususnya perkembangan kerajaan Sriwijaya.

Adapun hasil analisis isi prasasti Talang Tuo yang berhubungan dengan perkembangan agama Budha di Sriwijaya sehingga dapat memperkaya materi ajar tentang sejarah perkembangan agama Budha di Sriwijaya yang tertera pada silabus sejarah kelas X Sekolah Menegah Atas yaitu pada kompetensi dasar 3.5 dan 3.6.

a. Berdasarkan hasil terjemahan Coedes pada isi prasasti Talang Tuo yang terdiri dari 14 baris dapat dijelaskan relevansinya dengan perkembangan agama Budha di Sriwijaya yaitu berupa usaha Dapunta Hiyang Sri Jayanasa yang bertujuan untuk mensejahterakan rakayat dan pemerintahannya, masyarakat yang tertib, aman, teratur sesuai dengan dharma sekaligus menyelamatkan rakyatnya dari samsara atau penderitaan dunia. Dapunta Hiyang Sri Jayanasa dapat melakukan hal itu karena ia telah mampu atau dianggap mencapai tingkat kedewaan (sebagai dewa di dunia) dalam masa pemerintahannya. Proses pendewaan ini secara normatif diperoleh melalui Tantra, sebagai dewaraja ia dapat menjangkau pengertian yang luas dalam usaha menyelamatkan segala makhluk atas penderitaan.

b. Isi pada prasasti Talang Tuo selain menjelaskan raja Sriwijaya yang benar-benar penganut ajaran Budha yang taat maka dijelaskan juga pada isi prasasti Talang Tuo tentang jiwa kepemimpinan seorang raja Sriwijaya yang sangat bijaksana, adil, tegas dan taat beragama yaitu dibuktikan raja Dapunta Hiyang Sri Jayanasa telah memerintahkan untuk membuat taman Sriksetra yang di dalamnya terdapat tanaman bermanfaat bagi seluruh mahkluk seperti, tanaman kelapa, sagu, pohon aren, pinang, bambu dan tanaman lainnya dengan tujuan kesejahteraan bagi seluruh masyarakatnya. Taman Sriksetra dibuat pada tahun 606 Saka (684 Masehi), dapat dipahami bahwa pada saat itu Dapunta Hiyang Sri Jayanasa baru beberapa waktu menjalankan pemerintahannya, sehingga ia perlu menjalankan pemerintahan sesuai ajaran seorang budhis yang adil, bijaksana dan bersih dalam bertindak terutama terhadap kebijakan kepada masyarakat. Uraian pada isi prasasti 
Talang Tuo memang mencerminkan seoarang penguasa yang telah paham dan menghayati ajaran Budha. Dapat ditafsirkan untuk saat ini Dapunta Hiyang Sri Jayanasa telah menjadi seorang dewa, sedangkan masa sebelumnya ia belum sampai taraf sedemikian tinggi.

c. Pada kesimpulan selanjutnya dapat ditegaskan sesuai dengan Kompetensi Dasar pada silabus kelas $X$ Sekolah Menengah Atas (SMA) yaitu pada KD 3.5 dan KD 3.6 tentang perkembangan kerajaan Sriwijaya, terutama pada isi prasasti Talang Tuo dapat dijadikan sebuah materi ajar tentang perkembangang agama Budha di Sriwijaya. Perkembangan agama Budha yang dijelaskan pada parasasti Talang Tuo menunjukan betapa taatnya raja Sriwijaya dalam menjalankan ajaran Budha tercermin ia membangun sebuah taman yang di dalamnya terdapat tanamantanaman yang bermanfaat bagi masyarakat. Selain itu raja Sriwijaya benar-benar memperhatikan kesejahteraan masyarakatnya, adil, bijaksana yang semuanya sesuai ajaran pada agama Budha untuk saling menyayangi sesamanya, berbuat baik kepada manusia dan perbuatan baik lainnya. Analisis dari pada isi prasasti Talang Tuo mengenai pekembangan agama Budha di Sriwijaya menjelaskan dengan jelas pada abad ke-7 Masehi agama Budha sudah menjadi agama pemerintahan kerajaan Sriwijaya yang berpusat di Palembang. Meskipun bukti-bukti dan data-data tentang perkembangan agama Budha di Sriwijaya sudah ada berdasarkan temuan-temuan peninggalan Sriwijaya berupa arcaarca maupun bukti-bukti tertulis dari Cina tetapi pada dasarnya bukti yang tertulis dan informasi yang terdapat pada isi prasasti Talang Tuo dapat memberikan informasi yang sangat penting dan berharga bagi perkembangan agama Budha di Sriwijaya pada abad ke-7 Masehi.

\section{SIMPULAN}

Berdasarkan uraian hasil penelitian di atas maka penulis dapat menyimpulkan sebagai berikut:

1. Bermula nama Sriwijaya menjadi perdebatan bagi kalangan peneliti yang menyebutkan nama "Sriwijaya" yang tertulis pada prasasti Kota Kapur adalah nama seorang raja yang belum diketahui nama kerajaannya. Pada akhirnya G. Coedes pada tahun 1918 berpendapat berdasarkan hasil penelitiannya nama "Sriwijaya" adalah nama sebuah kerajaan. 
Pendapat G. Coedes tersebut didukung berdasarkan informasi catatan Cina dan bukti-bukti peninggalan kerajaan Sriwijaya di Palembang yang menyatakan nama lain kerajaaan Sriwijaya dalam catatan Cina disebut Shi-li-fo-shi. Kerajaan Sriwijaya dikenal sebagai kerajaan yang bercorak agama Budha dan kerajaan yang berkuasa di laut atau disebut sebagai kerajaan bercorak maritim pada abad ke-7 Masehi. Kekuasaanya sangat luas mencapai seluruh nusantara dan di luar nusantara.

2. Prasasti Talang Tuo adalah prasasti peninggalan kerajaan Sriwijaya, pada isi prasasti tertulis tahun 606 Saka (684 M), yang terdiri atas 14 baris dengan bahasa Melayu Kuno. Setelah prasasti tersebut diterjemahkan oleh G. Coedes, maka dapat dianalisis mengenai perkembangan dan kondisi agama Budha di pusat kerajaan Sriwijaya pada abad ke-7 Masehi. Perkembangan agama Budha pada masa kerajaan Sriwijaya dapat diketahui dari isi prasasti Talang Tuo yang menjelaskan raja Sriwijaya, Dapunta Hyang Sri Jayanasa adalah raja yang sangat taat menjalankan ajaran Budha dengan baik, ia dianggap sebagai dewa raja atau wakil di dunia yang berkuasa dan memiliki kepribadian yang baik, bijaksana dan tegas. Selain itu sebagai penjelmaan dewa yang harus membawa kebaikan bagi masyarakat atau semuanya, maka ia memerintahkan untuk membuat taman (sriketra) yaang memberikan manfaat bagi siapa saja. Melihat kebijakanya tersebut raja Sriwijaya seakan-akan menunjukan ketaatannya terhadap agamanya sehingga dianggap sebagai penyerupaan dewa.

3. Dari analisis isi prasasti Talang Tuo dapat dijelaskan bahwa perkembangan agama Budha di kerajaan Sriwijaya sudah berkembang dengan pesat. Dengan demikian isi prasasti Talang Tuo dapat dijadikan sumber materi ajar Sejarah Indonesia khususnya di Sekolah Menengah Atas. Alasan dapat dijadikan sebagai materi ajar karena sesuai dari pengembangan silabus Sejarah Indonesia di Sekolah Menengah Atas khususnya pada tingkat $X$ yaitu tepatnya pada Kompetensi Dasar (KD) 3.5 dan 3.6 tentang perkembangan kerajaankerajaan yang bercorak HinduBudha di Indonesia. Materi yang dimaksud adalah mengenai perkembangan kerajaan Sriwijaya yaitu tepatnya pada submateri perkembangan agama Budha di Sriwijaya.

\section{Saran-Saran}


Setelah selesai hasil penelitian ini, penulis memberikan saran-saranya diantaranya adalah:

1. Bagi para peminat sejarah terutama pada sejarah kerajaan Sriwijaya maka dengan selesainya hasil penelitian ini semoga menjadi inspirasi bagi peneliti dan pembaca untuk menumbuhkan jiwa nasionalisme sebagai generasi penerus dengan cara melakukan penelitian lanjutan tentang sejarah kelokalan.

2. Bagi pemerintah khususnya pemerintah daerah untuk meningkatkan partisipasinya dalam menjaga dan melestarikan sejarah kelokalan terutama sejarah lokal Palembang.

\section{DAFTAR PUSTAKA}

Codes, George. (2010). Asia Tenggara Masa Hindu-Budha, Jakarta: KPG Perpustakaan Populer Gramedia.

Codes, George. (2014). Kedatuan Sriwijaya, Depok: Komunitas Bambu.

Daliman. (2015). Metode Penelitian Sejarah, Yogyakarta: Penerbit Ombak.

Djavid, Boedenani. (1961). Tambo Kerajaan Sriwijaya sampai Berdirinya Kesultanan Palembang, Bandung: Tarate Bandung.

Fathurrohman, Pupuh, Sutekno. (2007). Strategi Belajar Mengajar. Bandung; IKAPI.

Mahmud, Kiagus Imron. (2008). Sejarah Palembang. Palembang: Anggrek.
Muljana, Slamet. (2006). Sriwijaya, Yogyakarta: PT. LkiS Pelangi Aksara.

Poesponegoro, Marwati Djoened, Nugroho Notosusanto. (1990). Sejarah Nasional Indonesia II. Jakarta: Balai Pustaka.

Read, Dick-Robert. (2008). Bukti-Bukti Mutakhir tentang Penjelajahan Pelaut Indonesia Abad Ke-5 Jauh sebelum Cheng Ho dan Columbus. (terjemahan), Bandung: Mizan.

Rapanie, Ahmad, dkk. (2012). Kerajaan Sriwijaya: beberapa Situs dan Artefaknya, Palembang: Dinas Pendidikan Museum Negeri Sumatera Selatan.

Suryanegara, Erwan bin Asnawi Jayanegara. (2009). Kerajaan Sriwijaya, Palembang: Dinas Pendidikan Provinsi Sumatera Selatan.

Siregar, Sondang M, dkk. (2001). Asia Tenggara dalam Perspektif Arkeologi: Kajian Arkeologi di Sumatera Selatan, Pelembang: Mendikbud dan Balai Arkeologi Palembang.

Tim Balai Arkeologi Palembang. (2006). Prasasti-prasasti Sriwijaya, Palembang: Dinas Pendidikan Nasional Museum Negeri Sumatera Selatan.

Tim Museum Balaputra Dewa. (2010). Koleksi Arkeologi Museum Balaputra Dewa, Palembang: Dinas Pendidikan dan Museum Balaputera Dewa.

Wolters, O.W. (2011). Kemaharajaan Maritim Sriwiaya dan Perniagaan Dunia Abad III - Abad VII. Jakarta: Komunitas Bambu. 
Prasasti Talang Tuo Peninggalan Kerajaan Sriwijaya..., Kabib Sholeh, 173-192 